\title{
Analisis Kualitas Pelayanan Minimarket Indomaret di Bandung untuk Meningkatkan Kepuasan Pelanggan
}

\author{
Sonna Kristina ${ }^{1}$, Marla Setiawati ${ }^{2}$, Shandy Sebastian ${ }^{3 *}$ \\ ${ }^{1,2,3}$ Program Studi Teknik Industri, Institut Teknologi Harapan Bangsa, Bandung, Indonesia \\ ( ${ }^{*}$ shandy.sebastian@yahoo.com)
}

\begin{abstract}
Abstrak - Kualitas pelayanan adalah salah satu faktor penentu yang penting untuk mempertahankan kinerja bisnis suatu perusahaan. Pelayanan yang berkualitas dapat membuat pelanggan puas yang sangat bermanfaat bagi perusahaan. Salah satu perusahaan yang perlu memberikan pelayanan yang berkualitas adalah Indomaret. Permasalahan pelayanan pada Indomaret terjadi karena pengalamam buruk konsumen yang mengakibatkan pelanggan kecewa. Perusahaan perlu memperbaiki kinerja pelayanannya untuk menutup kesenjangan yang terjadi agar masalah ini tidak berdampak buruk pada kinerja bisnisnya. Agar dapat memberikan pelayanan yang berkualitas, perusahaan perlu mengetahui ukuran kualitasnya saat ini serta kinerja yang menjadi prioritas perbaikan untuk meningkatkan kepuasan pelanggannya. Oleh sebab itu, penelitian ini disusun agar perusahaan mengetahui ukuran kualitas pelayanannya saat ini dan kinerja pelayanan yang menjadi prioritas perbaikan untuk meningkatkan kepuasan pelanggan sehingga perusahaan dapat memberikan pelayanan yang berkualitas. Metode yang digunakan dalam mengukur kualitas layanan adalah SERVQUAL, sedangkan untuk mengetahui prioritas perbaikannya dihasilkan dari penggabungan metode SERVQUAL dengan Importance Performance Analysis (IPA). Hasil pengukuran kualitas pelayanan Indomaret Bandung yang diperoleh adalah $\mathbf{- 0 . 2 6 7}$, yang artinya pelayanan yang diberikan belum berkualitas. Selain itu, terdapat 16 kinerja yang menjadi prioritas perbaikan untuk meningkatkan kepuasan pelanggan. Analisis kualitas pelayanan ini akan membantu perusahaan dalam mengevaluasi kinerja pelayanan perusahaan serta meningkatkan kualitas layanannya.
\end{abstract}

Kata kunci: Importance Performance Analysis; kualitas pelayanan; kepuasan pelanggan; SERVQUAL

\section{PENDAHULUAN}

Kualitas pelayanan adalah salah satu faktor penentu yang penting untuk mempertahankan kinerja bisnis suatu perusahaan. Dengan memberikan pelayanan yang berkualitas, pelanggan akan merasa puas karena pelayanan yang diberikan oleh perusahaan sesuai dengan yang diharapkan. Kepuasan pelanggan sendiri sangat bermanfaat bagi perusahaan. Menurut Tjiptono dan Fandy (1996), manfaat kepuasan pelanggan adalah untuk menjaga relasi perusahaan dengan para pelanggannya, mendorong terciptanya loyalitas pelanggan, mendorong konsumen melakukan pembelian ulang, membentuk suatu rekomendasi yang positif dari mulut ke mulut, dan dapat meningkatkan laba penjualan perusahaan. Salah satu perusahaan yang perlu memberikan pelayanan yang berkualitas adalah Indomaret.

Permasalahan yang berhubungan dengan pelayanan pada Indomaret terjadi di cabang Indomaret Bandung, karena pengalaman buruk konsumen yang disebabkan ketidakmampuan pegawai dalam memenuhi harapan konsumen. Akibatnya, pelanggan menjadi tidak puas dan merasa kecewa terhadap perusahaan karena harapannya tidak dipenuhi. Menurut Parasuraman dkk. (1988), fenomena ini menunjukkan bahwa terdapat kesenjangan pada pelayanan Indomaret. Apabila perusahaan tidak memperbaiki kinerja pelayanannya untuk memperkecil atau menutup kesenjangan yang terjadi, maka perusahaan lama-kelamaan tidak akan mampu mempertahankan kinerja bisnisnya. Berdasarkan portofolio tentang fakta-fakta konsumen yang diperoleh dari goldenstone, terdapat beberapa hal yang akan terjadi berhubungan dengan pelanggan yang tidak puas yaitu saat ada satu konsumen yang melakukan komplain karena tidak puas terhadap layanan perusahaan, secara bersamaan 26 konsumen lain yang tidak puas namun tidak komplain pindah ke toko lain, satu konsumen yang tidak puas akan menceritakan pengalamannya pada 9-15 orang dan sekitar 13\% diantaranya bercerita pada lebih dari 20 orang, sekitar $70 \%$ terjadinya transaksi dikarenakan faktor kesan konsumen terhadap pelayanan perusahaan, dan pelayanan yang berkualitas rendah adalah alasan utama konsumen meninggalkan perusahaan. Oleh karena itu, penting bagi minimarket Indomaret untuk memberikan pelayanan yang berkualitas agar dapat memuasakan pelanggannya.

Untuk memberikan pelayanan yang berkualitas, perlu dilakukan pengukuran. Pengukuran kualitas pelayanan penting untuk dilakukan karena dapat membantu perusahaan untuk memperbaiki/meningkatkan kinerjanya secara efektif dan efisien. Ada beberapa metode yang dapat digunakan untuk mengukur kualitas 
pelayanan, diantaranya adalah SERVQUAL dan SERVPERF. SERVQUAL mengukur kualitas pelayanan dengan menggunakan analisis kesenjangan antara persepsi dan ekspektasi, sedangkan SERVPERF hanya menggunakan persepsi dalam pengukurannya. Penelitian terdahulu menunjukkan bahwa pengukuran menggunakan SERVPERF lebih unggul dari SERVQUAL dari sisi tingkat validitas dan reliabilitas dalam menjelaskan pengaruh kualitas pelayanan terhadap kepuasan. Namun dalam pengukurannya, SERVPERF memiliki kekurangan yaitu dalam mendiagnosa/mengenali permasalahan pelayanan yang terjadi. Menurut penelitian Jain dan Gupta (2004), SERVQUAL lebih unggul daripada SERVPERF dalam mendiagnosa permasalahan pelayanan, sehingga dapat membantu pihak manajerial dalam meningkatkan kualitas pelayanan suatu perusahaan. Banyak peneliti yang mempelajari permasalahan kualitas pelayanan menyatakan bahwa analisis kesenjangan adalah alat ukur yang paling efektif untuk meningkatkan kepuasan pelanggan sebuah perusahaan (Lin dkk., 2009). Oleh karena itu, metode pengukuran yang digunakan untuk memecahkan masalah dalam penelitian ini adalah SERVQUAL dengan menggunakan lima dimensi kualitas pelayanan yang terdiri dari Responsiveness, Assurance, Tangible, Empathy, Reliability atau disingkat RATER sebagai elemen penentu pelayanan yang berkualitas.

Walaupun SERVQUAL dapat membantu untuk meningkatkan kualitas pelayanan, metode ini mengasumsikan bahwa perbaikan kinerja berbanding linier dengan kepuasan (Tan \& Pawitra, 2001), sehingga hasil perbaikan yang dihasilkan belum tentu tepat. Penggabungan metode SERVQUAL dengan Importance Performance Analysis (IPA) akan meningkatkan kekuatan analisis (Lin dkk., 2009), karena IPA berguna sebagai pedoman dalam mengalokasikan sumber daya organisasi yang terbatas pada bidang-bidang spesifik sehingga perbaikan kinerja yang dilakukan dapat berdampak besar pada kepuasan pelanggan (Rangkuti, 2008).

Oleh karena itu rumusan masalah dari penelitian ini adalah berapa hasil pengukuran kualitas pelayanan Indomaret Bandung saat ini dengan menggunakan metode SERVQUAL serta kinerja pelayanan apa saja yang menjadi prioritas perbaikan kinerja apa yang perlu dilakukan untuk meningkatkan kepuasan para pelanggannya. Adapun Batasan masalah dan asumsi yang digunakan dalam penelitian ini yaitu responden penelitian adalah pelanggan Indomaret wilayah Bandung Timur dan kinerja pelayanan yang diteliti adalah pelayanan saat pelanggan belanja offline di Indomaret. Responden penelitian yang dipilih adalah pelanggan Indomaret wilayah Badung Timur karena mayoritas gerai Indomaret di Bandung berada di Bandung Timur. Berdasarkan pencarian gerai-gerai Indomaret yang berada di Bandung dengan bantuan google maps pada 14 Juni 2021, sebanyak 45\% dari 277 gerai Indomaret yang ada di Bandung ditemukan di wilayah Timur, sehingga kualitas pelayanan Indomaret Badung Timur dianggap dapat menggambarkan kualitas pelayanan Indomaret di Bandung.

\section{STUDI LITERATUR}

\section{A. Kepuasan Pelanggan}

Kepuasan pelanggan adalah perasaan senang atau kecewa seseorang yang muncul setelah membandingkan kinerja (hasil) produk yang dipikirkan terhadap kinerja yang diharapkan (Kotler \& Keller, 2016). Salah satu faktor yang menentukan tingkat kepuasan pelanggan adalah kualitas pelayanan.

\section{B. Kualitas Pelayanan}

Kualitas pelayanan adalah kemampuan perusahaan untuk memberikan pelayanan yang sesuai dengan harapan konsumen yang berhubungan dengan produk, manusia, proses, tugas, dan lingkungan. Ada lima dimensi pembentuk pelayanan yang berkualitas yaitu Responsiveness, Assurance, Tangible, Empathy, dan Reliability (Parasuraman dkk., 1988).

\section{SERVQUAL}

SERVQUAL dibangun atas adanya perbandingan dua faktor, yaitu persepsi pelanggan atas layanan nyata yang mereka terima (perceived service) dengan layanan yang sesungguhnya diharapkan (expected service). Jika Perceived service $\geq$ expected service, pelayanan tersebut dikatakan berkualitas, sedangkan jika, perceived service < expected service, maka pelayanan dikatakan tidak berkualitas (Lupiyoadi \& Hamdani, 2013). 


\section{Importance Performance Analysis (IPA)}

IPA pertama kali diperkenalkan oleh Martila dan James pada tahun 1977 (Martila \& James, 1977). IPA digunakan untuk memetakan hubungan antara kepentingan atau tingkat harapan konsumen dengan kinerja dari masing-masing indikator (Yola \& Budianto, 2013). Fungsi utama IPA adalah untuk menampilkan informasi tentang faktor-faktor pelayanan yang menurut konsumen sangat mempengaruhi kepuasannya dan yang perlu diperbaiki karena pada saat ini belum memuasakan.

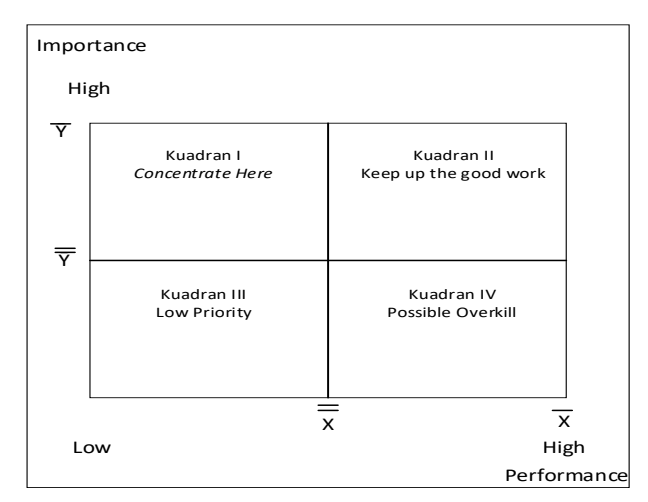

Gambar 1. Importance-Performance Matrix

Keterangan:

1) Kuadran I $\rightarrow$ Indikator yang berada pada wilayah ini, adalah indikator yang dianggap memiliki tingkat kepentingan yang tinggi, tetapi kinerja yang dirasakan belum sesuai dengan yang harapan pelanggan. Indikator-indikator pada wilayah ini harus segera ditingkatkan kinerjanya.

2) Kuadran II $\rightarrow$ Indikator pada wilayah ini adalah indikator yang memiliki tingkat kepentingan yang tinggi dan tingkat kinerja yang tinggi. Indikator yang masuk ke dalam wilayah ini perlu dipertahankan.

3) Kuadran III $\rightarrow$ Indikator pada wilayah ini adalah indikator yang memiliki tingkat kepentingan yang rendah dan tingkat kinerja yang rendah. Indikator yang masuk pada wilayah ini memberikan pengaruh yang kecil bagi kepuasan pelanggan.

4) Kuadran IV $\rightarrow$ Indikator pada wilayah ini adalah indikator yang memiliki tingkat kepentingan yang rendah, tetapi kinerja yang dirasakan terlalu tinggi. Biaya yang digunakan untuk menunjang indikator ini dapat dikurangi agar dapat menghemat pengeluaran biaya.

\section{METODOLOGI}

Berikut adalah langkah-langkah yang dilakukan dalam penelitian yang disajikan dalam diagram alir. 

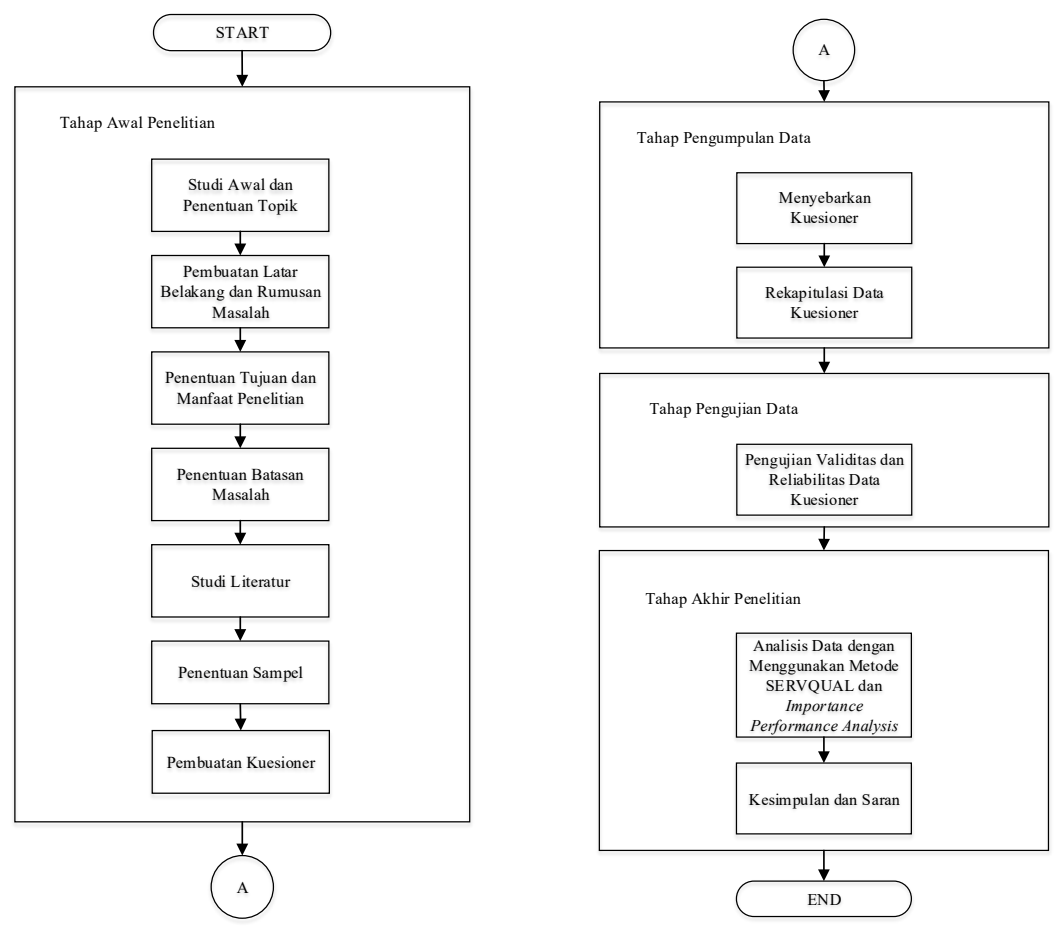

Gambar 2. Diagram Alir Metodologi Penelitian

\section{A. Penentuan Sampel}

Teknik pemilihan sampel pada tahap penentuan sampel menggunakan non-probability sampling. Menurut Sugiyono dalam Ghozali (2013), non-probability sampling adalah teknik yang tidak memberi peluang yang sama bagi setiap anggota populasi untuk dipilih menjadi sampel. Teknik non-probability sampling yang digunakan adalah purposive sampling, dengan karakteristik poulasi yaitu pelanggan Indomaret wilayah Bandung Timur serta pelanggan yang minimal memiliki frekuensi kunjungan ke minimarket Indomaret wilayah Bandung Timur sebanyak satu kali dalam sebulan.

Dikarenakan populasi dari sampel yang akan diteliti tidak diketahui, maka untuk menentukan jumlah sampel minimum menggunakan rumus Martanti (Pelupessy, 2018):

$$
n=\frac{Z^{2}}{4(M o e)^{2}}
$$

Dengan menggunakan taraf signifikansi $(\alpha) 5 \%$ dan margin of erorr (Moe) yang ditetapkan sebesar $10 \%$, maka jumlah sampel minimum yang dibutuhkan adalah 96.04 dan dibulatkan menjadi 97 sampel.

\section{B. Pembuatan Kuesioner}

Kuesioner dibuat menggunakan skala likert dengan skor 1-5 melalui google form link berdasarkan konsep dimensi pelayanan yang berkualitas. Responsiveness adalah ketersediaan pegawai minimarket untuk membantu dan memberikan pelayanan yang cepat dan tanggap pada pelanggan (Omar dkk., 2015). Indikator penelitian yang digunakan untuk mengukur dimensi responsiveness yaitu cepat tanggap dalam menyampaikan pelayanan kepada pelanggan (R1), cepat tanggap dalam dalam menangani keluhan (R2), ketersediaan membantu pelanggan (R3). Assurance adalah Pengetahuan dan kesopanan pegawai serta kemampuan pegawai untuk menyampaikan rasa percaya dan keyakinan pada pelanggan (Omar dkk., 2015). Indikator penelitian yang digunakan untuk mengukur dimensi assurance yaitu keamanan tempat parkir (A1), keamanan tempat belanja (A2), keamanan fasilitas pembayaran non-tunai (A3), kesopanan dalam pelayanan (A4), pelayanan yang menumbuhkan keyakinan pada pelanggan (A5), pegawai yang berpengetahuan (A6). Tangible adalah penampilan/rupa dari fasilitas fisik, peralatan, dan penampilan personalia yang sesuai dengan karakteristik pelayanan yang diberikan (Omar dkk., 2015). Indikator penelitian yang digunakan untuk mengukur dimensi tangible yaitu pegawai berpenampilan profesional (rapi, bersih, berseragam) (T1), pencahayaan ruang belanja 
(T2), ruang belanja bersih (T3), suhu ruang belanja nyaman (T4), peralatan untuk memudahkan pelanggan belanja (T5), penataan barang rapi (T6), kebersihan area parkir (T7), luas area parkir (T8), kebersihan toilet (T9). Empathy adalah kepedulian dan perhatian penyedia pelayanan kepada pelanggan seperti memperlakukan pelanggan sebagai individu (Omar dkk., 2015). Indikator penelitian yang digunakan untuk mengukur dimensi empathy yaitu kemudahan akses untuk menyampaikan kritik/saran/keluhan pelanggan (E1), pegawai menyambut kedatangan pelanggan (E2), pelayanan berkualitas tanpa memandang status sosial, etnis, agama, gender (E3), letak minimarket yang strategis sehingga mudah dijangkau (E4). Reliability adalah kemampuan untuk memberikan pelayanan yang terpercaya dan akurat kepada pelanggannya (Omar dkk., 2015). Indikator penelitian yang digunakan untuk mengukur dimensi reliability yaitu harga yang tercantum sesuai dengan harga di kasir (RE1), ketersediaan barang selalu terjaga (RE2), kemudahan dalam pembayaran (RE3), kemampuan pegawai kasir menghitung transaksi pembayaran dengan teliti (RE4), menyediakan pelayanan sesuai dengan yang dijanjikan (RE5), menyelenggarakan layanan pada waktu yang dijanjikan (RE6).

\section{Uji Validitas dan Uji Reliabilitas}

Pengujian validitas dan reliabilitas dilakukan pada 101 data hasil kuesioner sebelum data tersebut diolah. Uji validitas digunakan untuk mengukur sah atau tidaknya suatu kuesioner. Pengujian dilakukan dengan mengkorelasikan setiap skor pernyataan dengan skor totalnya. Jika $r$ hitung lebih besar atau sama dengan $r$ tabel ( $\mathrm{r}$ hitung $\geq \mathrm{r}$ tabel), item pernyataan dikatakan valid. Sebaliknya jika $\mathrm{r}$ hitung lebih kecil daripada $\mathrm{r}$ tabel ( $r$ hitung $<\mathrm{r}$ tabel), item pernyataan dikatakan tidak valid. Nilai $r$ tabel pada penelitian ini menggunakan tingkat signifikansi 5\%, sehingga nilai $r$ tabel dengan menggunakan degree of freedom (df): $n-2$ untuk pengujian dua arah (two-side) adalah 0.1956. Uji reliabilitas dilakukan untuk mengetahui tingkat keandalan suatu kuesioner. Kuesioner dikatakan reliabel jika kuesioner dapat mengungkapkan data yang bisa dipercaya dan sesuai dengan kenyataan yang sebenarnya. Metode pengujian reliabilitas yang yang digunakan adalah Cronbach's Alpha $(\alpha)$. Jika nilai $\alpha \geq 0.06$, kuesioner dianggap reliabel (Sugiyono, 2012). Dalam pengujian validitas dan reliabilitas, penelitian ini menggunakan software IBM SPSS statistics v24 untuk mempermudah dan mempercepat dalam pengujiannya.

\section{Analisis Data Dengan menggunakan SERVQUAL dan Importance Performance Analysis (IPA)}

Sebelum melakukan analisis kesenjangan dengan menggunakan SERVQUAL, dilakukan pembobotan pada hasil kuesioner yang diperoleh. Pemberian bobot dilakukan dengan menggunakan rumus pembobotan nilai SERVQUAL (Ismawati, 2013):

$$
\begin{aligned}
& \sum x i=\left(\sum X 1 \times 1\right)+\left(\sum X 2 \times 2\right)+\left(\sum X 3 \times 3\right)+\left(\sum X 4 \times 4\right)+\left(\sum X 5 \times 5\right) \\
& \sum y i=\left(\sum Y 1 \times 1\right)+\left(\sum Y 2 \times 2\right)+\left(\sum Y 3 \times 3\right)+\left(\sum Y 4 \times 4\right)+\left(\sum Y 5 \times 5\right)
\end{aligned}
$$

Kemudian bobot tersebut dirata-rata dengan rumus (Ismawati, 2013):

$$
\begin{aligned}
& \bar{X}_{i}=\frac{\sum x i}{n} \\
& \bar{Y}_{i}=\frac{\sum y i}{n}
\end{aligned}
$$

Keterangan:

$\sum \mathrm{Xi}, \sum \mathrm{Yi}=$ jumlah bobot jawaban persepsi, ekspektasi

$\bar{X}_{l} \quad=$ rata-rata bobot jawaban persepsi

$\overline{Y_{l}} \quad=$ rata-rata bobot jawaban ekspektasi

$\mathrm{n} \quad=$ jumlah responden

Setelah dilakukan pembobotan, dilakukan analisis dengan menggunakan SERVQUAL untuk mengetahui ukuran kualitas pelayanan dan kesenjangan yang terjadi, serta perbaikan yang perlu dilakukan manajer perusahaan untuk memperkecil kesenjangan pelayanan yang terjadi dengan menggabungkan hasil 
SERVQUAL dan IPA yang diperoleh. Untuk mempermudah dalam peletakan koordinat setiap indikator pada matriks IPA, digunakan software IBM SPSS statistics v24.

\section{HASIL DAN PEMBAHASAN}

\section{A. Uji Validitas dan Uji Reliabilitas}

Hasil uji validitas dan reliabilitas perceived service dan expected service pada 101 responden menunjukan bahwa seluruh variabel valid dan reliabel.

Tabel 1

Hasil Uji Validitas

\begin{tabular}{|c|c|c|c|c|}
\hline \multirow{2}{*}{ Variabel } & \multicolumn{2}{|c|}{ R Hitung } & \multirow{2}{*}{ R Tabel } & \multirow{2}{*}{ Keterangan } \\
\hline & Persepsi & Ekspektasi & & \\
\hline R1 & 0.487 & 0.673 & 0.1956 & Valid \\
\hline R2 & 0.543 & 0.573 & 0.1956 & Valid \\
\hline R3 & 0.522 & 0.532 & 0.1956 & Valid \\
\hline A1 & 0.593 & 0.708 & 0.1956 & Valid \\
\hline $\mathrm{A} 2$ & 0.489 & 0.552 & 0.1956 & Valid \\
\hline A3 & 0.577 & 0.587 & 0.1956 & Valid \\
\hline A4 & 0.673 & 0.744 & 0.1956 & Valid \\
\hline A5 & 0.602 & 0.667 & 0.1956 & Valid \\
\hline A6 & 0.632 & 0.570 & 0.1956 & Valid \\
\hline $\mathrm{T} 1$ & 0.700 & 0.705 & 0.1956 & Valid \\
\hline $\mathrm{T} 2$ & 0.738 & 0.781 & 0.1956 & Valid \\
\hline T3 & 0.726 & 0.814 & 0.1956 & Valid \\
\hline $\mathrm{T} 4$ & 0.722 & 0.805 & 0.1956 & Valid \\
\hline T5 & 0.648 & 0.660 & 0.1956 & Valid \\
\hline T6 & 0.707 & 0.707 & 0.1956 & Valid \\
\hline $\mathrm{T} 7$ & 0.732 & 0.732 & 0.1956 & Valid \\
\hline T8 & 0.597 & 0.615 & 0.1956 & Valid \\
\hline T9 & 0.578 & 0.605 & 0.1956 & Valid \\
\hline E1 & 0.511 & 0.540 & 0.1956 & Valid \\
\hline E2 & 0.642 & 0.604 & 0.1956 & Valid \\
\hline E3 & 0.717 & 0.742 & 0.1956 & Valid \\
\hline E4 & 0.724 & 0.751 & 0.1956 & Valid \\
\hline RE1 & 0.707 & 0.758 & 0.1956 & Valid \\
\hline RE2 & 0.695 & 0.745 & 0.1956 & Valid \\
\hline RE3 & 0.648 & 0.568 & 0.1956 & Valid \\
\hline RE4 & 0.760 & 0.795 & 0.1956 & Valid \\
\hline RE5 & 0.772 & 0.783 & 0.1956 & Valid \\
\hline RE6 & 0.694 & 0.754 & 0.1956 & Valid \\
\hline
\end{tabular}

Tabel 2

Hasil Uji Reliabilitas

\begin{tabular}{|c|c|c|c|c|}
\hline \multirow[b]{2}{*}{$N$ of Items } & \multicolumn{2}{|c|}{ Cronbach's Alpha Variabel } & \multirow[b]{2}{*}{ Cronbach's Alpha } & \multirow[b]{2}{*}{ Keterangan } \\
\hline & Persepsi & Ekspektasi & & \\
\hline 28 & 0.939 & 0.944 & $\geq 0.600$ & Valid \\
\hline
\end{tabular}

\section{B. SERVQUAL}

Setelah diketahui bahwa seluruh variabel valid dan reliabel, penelitian dilanjutkan dengan melakukan gap analysis pada pelayanan Indomaret Bandung. Ada tiga kesenjangan/gap yang mungkin terjadi (Supranto, 2006), yaitu gap $=0$ (pelanggan puas), gap $>0$ (pelanggan sangat puas), gap $<0$ (pelanggan tidak puas). 
Tabel 3

Pengukuran Kualitas Pelayanan Indomaret

\begin{tabular}{|c|c|c|c|c|}
\hline Variabel & Perspesi & Ekspektasi & Gap & Ranking \\
\hline R1 & 3.564 & 4.109 & -0.545 & 2 \\
\hline R2 & 3.500 & 3.977 & -0.477 & 4 \\
\hline R3 & 3.648 & 3.989 & -0.341 & 8 \\
\hline A1 & 3.941 & 4.198 & -0.257 & 13 \\
\hline A2 & 3.700 & 4.140 & -0.440 & 5 \\
\hline A3 & 3.835 & 4.033 & -0.198 & 18 \\
\hline A4 & 4.030 & 4.238 & -0.208 & 17 \\
\hline A5 & 4.099 & 4.208 & -0.109 & 24 \\
\hline A6 & 3.706 & 3.988 & -0.282 & 11 \\
\hline T1 & 4.040 & 4.139 & -0.099 & 25 \\
\hline T2 & 4.188 & 4.149 & 0.040 & 28 \\
\hline T3 & 4.079 & 4.228 & -0.149 & 23 \\
\hline T4 & 4.109 & 4.188 & -0.079 & 27 \\
\hline T5 & 3.793 & 3.989 & -0.196 & 19 \\
\hline T6 & 3.970 & 4.129 & -0.158 & 22 \\
\hline T7 & 3.673 & 3.950 & -0.277 & 12 \\
\hline T8 & 3.745 & 4.092 & -0.347 & 6 \\
\hline T9 & 3.372 & 4.012 & -0.640 & 1 \\
\hline E1 & 3.526 & 3.872 & -0.346 & 7 \\
\hline E2 & 3.832 & 3.931 & -0.099 & 26 \\
\hline E3 & 3.891 & 4.149 & -0.257 & 14 \\
\hline E4 & 4.050 & 4.287 & -0.238 & 16 \\
\hline RE1 & 3.960 & 4.297 & -0.337 & 9 \\
\hline RE2 & 3.614 & 4.158 & -0.545 & 3 \\
\hline RE3 & 3.855 & 4.145 & -0.289 & 10 \\
\hline RE4 & 4.129 & 4.297 & -0.168 & 21 \\
\hline RE5 & 3.941 & 4.198 & -0.257 & 15 \\
\hline RE6 & 4.089 & 4.267 & -0.178 & 20 \\
\hline & & & & \\
\hline
\end{tabular}

Berdasarkan hasil pengukuran kualitas pelayanan Indomaret, rata-rata seluruh kesenjangan yang dihasilkan adalah -0.267 (tidak berkualitas). Ranking disusun berdasarkan besar nilai ketidakpuasan atas pelayanan.

\section{Importance Performance Analysis (IPA)}

Setelah diperoleh hasil pengukuran kualitas dengan menggunakan SERVQUAL, penelitian dilanjutkan dengan mengklasifikasikan setiap indikator pada matriks $2 \times 2$, untuk mencari prioritas perbaikan yang perlu dilakukan.

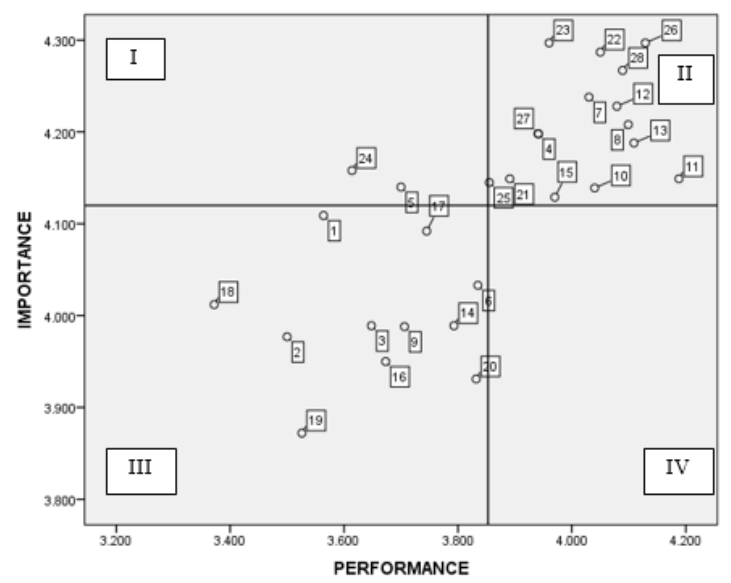

Gambar 3. Importance-Performance Matrix Pelanggan Indomaret 


\section{Hubungan SERVQUAL dengan IPA dalam Perbaikan Kinerja untuk Meningkatkan Kepuasan Pelanggan}

Penggunaan metode SERVQUAL dan IPA dalam perbaikan kinerja pelayanan adalah untuk meningkatkan keefektifan solusi perbaikan yang dihasilkan. Metode SERVQUAL dapat membantu manajer dalam mengetahui kesenjangan-kesenjangan yang terjadi dari kinerja pelayanan yang diberikan dan solusi perbaikan yang dilakukan untuk memperkecil atau menutup kesenjangan tersebut. Namun, perbaikan yang dihasilkan belum tentu tepat dalam arti perbaikan yang dilakukan mungkin tidak berdampak besar pada kepuasan pelanggan karena perbaikan solusi yang dihasilkan dari metode ini sesuai dengan besarnya kesenjangan atau kepuasan yang dihasilkan. Oleh karena itu, perlu tambahan metode Importance Performance Analysis (IPA). IPA dapat membantu dalam mengklasifikasikan setiap data tersebut ke dalam kuadran, sehingga membantu manajer untuk tidak salah dalam mengalokasikan sumber daya saat melakukan perbaikan dan dampak yang dihasilkan besar pada kepuasan pelanggan.

Penggabungan konsep dan hasil pengolahan data dan analisis berdasarkan SERVQUAL dan IPA untuk mendapatkan hasil perbaikan yang lebih efektif. Perbaikan disusun berdasarkan kuadran. Kemudian pada kuadran concentrate here dan keep up the good work, perbaikan diurutkan berdasarkan besarnya gap yang terjadi, sedangkan untuk kuadran low priority diurutkan berdasarkan besarnya importance.

Tabel 4

Perbaikan Kinerja Pelayanan Indomaret

\begin{tabular}{|c|c|c|c|c|}
\hline Variabel & Gap & Kuadran & Importance & Ranking \\
\hline RE2 & -0.545 & Concentrate Here & 4.158 & 1 \\
\hline A2 & -0.440 & Concentrate Here & 4.140 & 2 \\
\hline RE1 & -0.337 & Keep Up the Good Work & 4.297 & 3 \\
\hline RE3 & -0.289 & Keep Up the Good Work & 4.145 & 4 \\
\hline A1 & -0.257 & Keep Up the Good Work & 4.198 & 5 \\
\hline E3 & -0.257 & Keep Up the Good Work & 4.149 & 6 \\
\hline RE5 & -0.257 & Keep Up the Good Work & 4.198 & 7 \\
\hline E4 & -0.238 & Keep Up the Good Work & 4.287 & 8 \\
\hline A4 & -0.208 & Keep Up the Good Work & 4.238 & 9 \\
\hline RE6 & -0.178 & Keep Up the Good Work & 4.267 & 10 \\
\hline RE4 & -0.168 & Keep Up the Good Work & 4.297 & 11 \\
\hline T6 & -0.158 & Keep Up the Good Work & 4.129 & 12 \\
\hline T3 & -0.149 & Keep Up the Good Work & 4.228 & 13 \\
\hline A5 & -0.109 & Keep Up the Good Work & 4.208 & 14 \\
\hline T1 & -0.099 & Keep Up the Good Work & 4.139 & 15 \\
\hline T4 & -0.079 & Keep Up the Good Work & 4.188 & 16 \\
\hline T2 & 0.040 & Keep Up the Good Work & 4.149 & \\
\hline R1 & -0.545 & Low Priority & 4.109 & 17 \\
\hline T8 & -0.347 & Low Priority & 4.092 & 18 \\
\hline A3 & -0.198 & Low Priority & 4.033 & 19 \\
\hline T9 & -0.640 & Low Priority & 4.012 & 20 \\
\hline T5 & -0.196 & Low Priority & 3.989 & 21 \\
\hline R3 & -0.341 & Low Priority & 3.989 & 22 \\
\hline A6 & -0.282 & Low Priority & 3.988 & 23 \\
\hline R2 & -0.477 & Low Priority & 3.977 & 24 \\
\hline T7 & -0.277 & Low Priority & 3.950 & 25 \\
\hline E2 & -0.099 & Low Priority & 3.931 & 26 \\
\hline E1 & -0.346 & Low Priority & 3.872 & 27 \\
\hline & & & & \\
\hline
\end{tabular}

Berdasarkan hasil perbaikan dengan menggabungkan metode SERVQUAL dan IPA, diperoleh urutan perbaikan yang membantu perusahaan dalam mengalokasikan sumber dayanya dalam meningkatkan kualitas pelayanannya secara efektif dan efisien. Urutan tersebut disusun berdasarkan kinerja yang perlu diperbaiki agar dapat berdampak besar pada kepuasan pelanggan. Setelah itu, mencari masalah yang menjadi penyebab terjadinya kesenjangan dalam pelayanan untuk diperbaiki agar dapat memperkecil kesenjangan yang terjadi. 


\section{KESIMPULAN}

1. Berdasarkan hasil analisis pada lima variabel pembentuk pelayanan berkualitas (responsiveness, assurance, tangible, empathy, reliability) dengan menggunakan metode SERVQUAL, hasil rata-rata keseluruhan kesenjangan pelayanan Indomaret Bandung yang diperoleh adalah -0.267 (Gap $<0$ ) yang artinya pelayanan yang diberikan belum berkualitas karena pelayanan Indomaret belum bisa memuaskan atau belum berhasil memberikan pelayanan sesuai dengan yang diharapkan pelanggan-pelanggannya.

2. Berdasarkan hasil analisis perbaikan yang dilakukan dengan menggunakan metode SERVQUAL dan IPA, terdapat 16 kinerja yang menjadi prioritas perbaikan untuk meningkatkan kepuasan pelanggan Indomaret Bandung. Pihak manajemen Indomaret harus melakukan perbaikan pada kinerja pelayanannnya untuk meningkatkan kepuasan para pelanggan dengan cara sebagai berikut:

Tabel 5

Usulan Perbaikan Pelayanan Indomaret

\begin{tabular}{|c|c|}
\hline Variabel & Saran \\
\hline RE2 & $\begin{array}{l}\text { Training pegawai minimarket yang bersangkutan agar pegawai tersebut dapat mengelola persediaan } \\
\text { barang di minimarket dengan baik. }\end{array}$ \\
\hline A2 & $\begin{array}{l}\text { Pihak Indomaret Bandung perlu menertibkan tukang parkir yang beroperasi di area parkir minimarket } \\
\text { agar mereka tetap harus mentaati protokol kesehatan yang ditetapkan oleh pemerintah dan tidak } \\
\text { memaksa pelanggan untuk membayar parkir. }\end{array}$ \\
\hline RE1 & $\begin{array}{l}\text { Pegawai minimarket yang bersangkutan perlu di training agar disiplin dalam membarui label harga } \\
\text { setiap ada perubahan harga. }\end{array}$ \\
\hline RE3 & $\begin{array}{l}\text { 1. Memiliki infrastruktur dan teknologi cadangan untuk mengatasi gangguan yang terjadi dengan } \\
\text { cara beralih ke infrastruktur dan teknologi cadangan, sehingga sistem pembayaran non-tunai } \\
\text { masih bisa berjalan. } \\
\text { 2. Pelatihan pegawai terutama pegawai baru agar lebih terampil dalam menggunakan fasilitas } \\
\text { pembayaran non-tunai. } \\
\text { Pelatihan supervisor agar dapat mengawasi pegawai kasir yang berkerja sehingga pegawai kasir } \\
\text { menjadi disiplin dan tidak malas-malasan. }\end{array}$ \\
\hline A1 & $\begin{array}{l}\text { Sebelum pelanggan masuk ke dalam minimarket, sebaiknya ada pegawai yang menunggu di depan } \\
\text { pintu untuk mengecek suhu tubuh dan masker pelanggan. }\end{array}$ \\
\hline E3 & $\begin{array}{l}\text { Pegawai minimarket frontliner perlu dilatih agar dapat memberikan pelayanan yang terbaik dan } \\
\text { berkualitas tanpa memandang penampilan para pelanggannya. }\end{array}$ \\
\hline RE5 & $\begin{array}{l}\text { Sebelum barang promo diiklankan, sebaiknya ada komunikasi antara departemen periklanan dengan } \\
\text { gerai-gerai minimarket dan antara departemen periklanan dengan departemen yang mengurus sistem } \\
\text { harga agar jika pelanggan menayakan barang promo pegawai minimarket tahu serta saat dipindai } \\
\text { secara otomatis sistem menggunakan harga promo pada barang yang bersangkutan. }\end{array}$ \\
\hline E4 & $\begin{array}{l}\text { Perlu didirikannya gerai minimarket di wilayah Bandung yang belum ada Indomaretnya namun tetap } \\
\text { memiliki potensi pasar yang besar agar mudah dijangkau oleh pelanggan. }\end{array}$ \\
\hline A4 & $\begin{array}{l}\text { Training pegawai frontliner di minimarket agar dapat terampil dan konsisten dalam memberikan } \\
\text { pelayanan yang sopan pada para pelanggan. }\end{array}$ \\
\hline RE6 & $\begin{array}{l}\text { Training pada manajer tiap gerai agar dapat mendisiplinkan pegawai-pegawainya untuk buka sesuai } \\
\text { dengan kebijakan yang sudah dibuat. }\end{array}$ \\
\hline RE4 & $\begin{array}{l}\text { Training pegawai kasir untuk mengurangi human error yang dilakukan pegawai dalam } \\
\text { mengoperasikan mesin kasir dan memberikan kembalian serta penambahan proses untuk meminta } \\
\text { pelanggan mengecek setruk dengan barang yang dibeli sebelum meninggalkan minimarket pada SOP } \\
\text { pegawai kasir. }\end{array}$ \\
\hline T6 & $\begin{array}{l}\text { Pegawai minimarket perlu memeriksa kerapian barang secara berkala, dan merapikan barang jika ada } \\
\text { yang tersimpan tidak pada tempatnya. }\end{array}$ \\
\hline T3 & Pegawai minimarket perlu membersihkan ruangan secara berkala agar ruang belanja tidak berdebu. \\
\hline A5 & $\begin{array}{l}\text { Pegawai kasir perlu didorong agar disiplin dalam memberikan setruk pada pelanggan dengan cara } \\
\text { membuat tulisan yang dipasang di depan mesin kasir "Jika Anda tidak diberi setruk, pembelian Anda } \\
\text { gratis" pada setiap gerai minimarket Indomaret. }\end{array}$ \\
\hline $\mathrm{T} 1$ & $\begin{array}{l}\text { Pada waktu istirahat atau ada waktu senggang sebaiknya pegawai mengurus dirinya. Hal tersebut } \\
\text { dapat dilakukan dengan cara pegawai mencuci wajahnya dengan air dingin atau mencuci wajah } \\
\text { dengan sabun agar terlihat tetap segar saat melayani pelanggan, dan lain-lain. }\end{array}$ \\
\hline $\mathrm{T} 4$ & $\begin{array}{l}\text { Meningkatkan kenyamanan suhu ruangan dengan cara mengatur suhu agar tidak terlalu dingin } \\
\text { ataupun terlalu panas dan melakukan maintenance AC 3-6 bulan sekali secara berkala agar dapat } \\
\text { berfungsi dengan baik. }\end{array}$ \\
\hline
\end{tabular}




\section{DAFTAR PUSTAKA}

Ghozali, I. (2013). Aplikasi Multivariate dengan Program SPSS Edisi Ketujuh. Semarang: Badan Penerbit Universitas Dipenogoro.

Golden Stone. 14 Fakta Customer. https:/goldenstone-id.com/portfolio/14-fakta-customer/.

Ismawati, Intan (2013). Analisis Kepuasan Pelanggan dan Loyalitas Pelanggan Dealer Nissan Cabang Padjajaran (Studi kasus pada Dealer Nissan Cabang Padjajaran Bogor). [Unpublished doctoral dissertation]. Institut Pertanian Bogor.

Jain, S.K., Gupta, G. (2004). Measuring service quality: SERVQUAL vs SERVPERF Scales. VIKALPA, 29(2), 25-37.

Kotler, P. \& Keller, K. L. (2016). Marketing Management (15th ed.). Pearson Education, Inc.

Lin, S.-P., Chan, Y.-H., \& Tsai, M.-C. (2009). A Transformation Function Corresponding to IPA and Gap Analysis. Total Quality Management, 20(8), 829-846.

Lupiyoadi, R. \& Hamdani A. (2013). Manajemen Pemasaran Jasa Berbasis Kompetensi Edisi 3. Jakarta: Salemba Empat.

Martilla, J.A. and James, J.C. (1977). Importance-Performance Analysis. Journal of Marketing, 41(1), 77-79.

Omar, M. S., Ariffin, H. F., \& Ahmad, R. (2015). Service Quality, Customers' Satisfaction and the Moderating Effects. 6th International Research Symposium in Service Management.

Parasuraman, A., Zeithaml, V. A., \& Berry, L. L. (1988). SERVQUAL: A Multiple Item Scale for Measuring Consumer Perception of Service Quality. Journal of Retailing, 64(1), 12-37.

Pelupessy, M. M. (2018). Analisis Pengaruh Promosi dan Harga terhadap Keputusan Pembelian Besi Putih di Kota Ambon (Studi Empiris pada Toko Besi Putih Asli (Khas) Maluku di Kota Ambon. Jurnal SOSOQ. 6(1), 106-117.

Rangkuti, F. (2008). Measuring Customer Satisfaction: Teknik Mengukur dan Strategi Meningkatkan Kepuasan Pelanggan Plus Analisis Kasus PLN-JP. Jakarta: PT. Gramedia Pustaka Utama.

Sugiyono (2012). Metode Penelitian Kuantitatif dan R\&d. Bandung: Alfabeta.

Supranto, J. (2006). Pengukuran Tingkat Kepuasan Pelanggan. Jakarta: Rineka Cipta.

Tan, K.C. \& Pawitra, T.A. (2001). Integrating SERVQUAL and Kano's Model into QFD for Service Excellence Development. Managing Service Quality: An International Journal, 11(6), 418-430.

Tjiptono, F. (1996). Manajemen Jasa. Yogyakarta: Andi.

Yola, M. \& Budianto, D. (2013). Analisis Kepuasan Konsumen terhadap Kualitas Pelayanan dan Harga Produk pada Supermarket dengan Menggunakan Metode Importance Performance Analysis (IPA). Jurnal Optimasi Sistem Industri, 12(12), 301-309. 